\title{
A Necessity to Specify the Species and Geographical Indication Tag of Trichoderma, a Biocontrol Agent for Soil Borne Plant Pathogens, on Commercial Packets of the Product
}

\section{Borkar SG*}

Plant Disease Diagnostic and Research Centre, Endeavour Scientific Agriculture, India

*Corresponding author: Borkar's Soil, Seed, Plant Disease Diagnostic and Research Centre, Endeavour Scientific Agric, 103, Prestige point Complex, In front of Nashik Road Police Station, Nashik, 422 101, Maharashtra state, India, Email: borkarsg@yahoo.co.in

\section{Case Report}

Volume 4 Issue 7

Received Date: October 10, 2020

Published Date: November 04, 2020

DOI: $10.23880 /$ jenr-16000219

\section{Abstract}

Research on Trichoderma species for its in vitro efficacy against soil borne fungal plant pathogens have been widely published for more than half a century and in vivo efficacy has also been reported for several species and their strains in their geographical locations of prevalence. However, the efficacy of a particular strain or an isolate of a species across the geographical location is not yet fully explored. This is the reason, why biocontrol agent Trichoderma has not yet achieved its impact in the agricultural production system as compared to commercial synthetic fungicides for control of plant pathogens. The available literature indicated that several environmental factors, soil ecology and geographical location specificity plays an important role in the efficacy of Trichoderma as biocontrol agent in the control of soil borne plant pathogens. Nevertheless, commercial formulation product of different Trichoderma species or unknown species are available as biocontrol agent of plant pathogens around the world, notably to be used in the organic farming system. Though different Trichoderma species are registered for their bio-formulation products in different countries, seldomly the name of a species of Trichoderma and its geographical indication tag are mentioned on the packet of commercial formulation. The geographical indication tag is available for the crop plant varieties/cvs, but not for Trichoderma species and strains; the crop varieties are recommended specifically for the particular geographical region or state or for whole the country based on the research trials, but this phenomenon is not in operation for release and recommendation of biocontrol agent. The Trichoderma species in the commercial formulation may be geographical specific for their biocontrol efficacy as evident in our research. Therefore, In the free trading era and movement of products across the regions, it becomes difficult to know that in the commercial formulation which species of Trichoderma is used as a biocontrol agent, its geographical indication tag and for which geographical area the biocontrol agent is recommended to work efficiently. Some species of Trichoderma are specific and effective for the control of certain soil borne fungal and nematode plant pathogens while other species are not effective for the same. Therefore, it seems to be important to specify the species of Trichoderma and its geographical indication tag on packet of commercial formulation product and the recommended geographical region for its biocontrol efficacy so as to derive the maximum advantage of the biocontrol product and the research carried out in this field.

Keywords: Biocontrol Agent; Trichoderma; Commercial Product; Efficacy; Geographical Indication Tag 


\section{Journal of Ecology and Natural Resources}

\section{Introduction}

The fungus Trichoderma and its species are well known and documented biocontrol agent of soil borne fungal and nematode plant pathogens around the world [1-4]. Different species of Trichoderma are distributed in different ecological soil system as soil inhabitant as well as epiphytic fungus [5-7]. The genus Trichoderma has 104 species registered internationally [8], two dozen of which are known as biocontrol agent [9] for soil borne fungal disease pathogens. However, these species are specific in their efficacy against the disease pathogen $[10,11]$. Further, strain variation in the species may exist which affect the biocontrol efficacy [12]. The geographical indication of the species or strain is also an important issue in the bio-efficacy of the strain, which is not discussed earlier. Geographical indication tag is given to the land races of the crop plant species which is specific for that area and perform better in that geographical location $[13,14]$. Similarly, the crop varieties are release and recommended for a particular geographical area, or a state or for whole the country based on its research trials across the regions. However, for the biocontrol agent Trichoderma, no such issue of geographical indication tag or a release and recommendation for a geographical region or state or for entire country is yet discussed and made operational. In the present paper, the issue of specifying the species of Trichoderma and its geographical indication tag on the packet of commercial formulation product and the geographical area of its utilization as biocontrol agent to obtain the better results of bio-control is analysed and discussed, in the light of our own research finding, for their necessity in the larger interest of farmers and plant disease management.

\section{Case Study}

Weindling [15] demonstrated for the first time the importance of Trichoderma as bio-agent for other fungi. The fungus Trichoderma and its species have gained immense importance since last few decades due to its biocontrol ability against several plant pathogens $[16,17,6]$ and different authors reported different species of Trichoderma as effective bio-agent for control of many soil borne fungi (Table 1) and the diseases caused by them.

\begin{tabular}{|c|c|c|}
\hline Trichoderma species & Effective against pathogen & References \\
\hline \multirow[b]{2}{*}{ T. atroviride } & Rhizoctonia solani, Pythium ultimatum. & Brunner [18] \\
\hline & $\begin{array}{c}\text { Esca disease pathogen: Armillaria mellea and A. gallica, } \\
\text { Phaeomoniella chlamydospora, Phaeoacremonium } \\
\text { aleophilum, Fomitiporia mediterrance. }\end{array}$ & Savazzini [19] \\
\hline T. citrinoviride & Botrytis cinerea, Cylindrocarpon & Park and Bue [22] \\
\hline T. flavofuscum & Pythium $s p$ & Patil [23] \\
\hline \multirow{3}{*}{ T. hamatum } & Rhizoctonia and Pythium & Chung \& Hoitink [24] \\
\hline & Fusarium.o.sp.lentis & El-Hassan [25] \\
\hline & Sclerotium rolfsii. & Borkar [26] \\
\hline \multirow{3}{*}{ T. koningii } & $\begin{array}{c}\text { Sclerotinia sclerotiarum.Fusarium oxysporium, F. solani, } \\
\text { Alternaria solani, Rhizoctonia solani. }\end{array}$ & Trutmann [27] \\
\hline & Pythium sp. & Shaikh \& Sahera [28] \\
\hline & Fusarium solani and Fusarium oxysporium. & Hadar [29] Karampour \& Okhowat [30] \\
\hline \multirow{5}{*}{ T. longibrachiatum } & Heterodera avenae. & Zhang [31] \\
\hline & Meloidogyne incognita. & Zhang \& Xu [10] \\
\hline & M. javanica. & Sokhandani [4] \\
\hline & Scutellonema sp, Helicotylenchus sp. & Chanu [32] \\
\hline & Rhizoctonia solani, Sclerotium rolfsii. & Sreenivasaprasad \& Sreenivasaprasad [33] \\
\hline T. pululiferum & No data available & \\
\hline T. Polysporum & Fusarium.o.ciceris. & Moutassem [11] \\
\hline \multirow{4}{*}{ T. pseudokoningii } & F. oxysporium, S. rolfsii. & Cuevas [34] \\
\hline & Pyricularia oryzae. & Khanzada \& Shah [35] \\
\hline & Fusarium wilt. & Cong [36] \\
\hline & Alternaria alternata. & Thakur \& Harsh [37] \\
\hline T. lignorum & No data available & \\
\hline
\end{tabular}




\begin{tabular}{|c|c|c|}
\hline T. aureoviride & Fusarium oxysporium. & Clavet [38] \\
\hline \multirow{3}{*}{ T. viren } & Macrophomina phaseolina. & Maheshwari [39] \\
\hline & Rhizoctonia solani. & Kumar [40] \\
\hline & Pseudomonas syringae. & Salas-Marina [41] \\
\hline \multirow{15}{*}{ T. viride } & Microphomina phaseolina. & Kehri \& Chandra [42] \\
\hline & Fusarium.o.sp.adzuki. & Manjunatha [43] \\
\hline & \multirow{4}{*}{ Fusarium oxysporium. } & John [44] \\
\hline & & Morshed [45] \\
\hline & & Osman [46] \\
\hline & & Sesan [1] \\
\hline & Pythium debaryanum, Rhizoctonia solani, Fusarium spp. & Singh \& Drivedi [47] \\
\hline & Sclerotium rolfsii. Fusarium oxysporium. & $\begin{array}{c}\text { Dhedi [48] Shahida [49]Kharampour \& } \\
\text { Okhowat [30] }\end{array}$ \\
\hline & Fusarium solani. & Madne [50] \\
\hline & Fusarium oxysporium. & Somashekhar [12] \\
\hline & Fusarium udum (isolate $\mathrm{H}$ ). & $\begin{array}{c}\text { Prasad \& Rangeswaran, [51] Kharakrang } \\
{[52]}\end{array}$ \\
\hline & Sclerotium rolfsii. & Prasad [53] \\
\hline & R. solani. & Sharma [54] \\
\hline & F.o.f.sp.ciceri. & Kapoor [2] \\
\hline & Fo.f.sp.lini. Sclerotium rolfsii. & Ahamed \& Vermette, \\
\hline \multirow{17}{*}{ T. harzianum } & Phytophthora capsici. & Mastouri \\
\hline & Pythium ultimatum. & Ferrigo \\
\hline & F. verticillioides, Botrytis cinera. & Kharakrang [52] \\
\hline & Rhizoctonia solani. & Prasad [53] \\
\hline & F.o.f.sp.ciceri. & Jayalaxmi \\
\hline & F. udum. & Mayur \& Deshmukh, \\
\hline & Chickpea wilt. & Sharma [54] \\
\hline & F.o.f.sp.lini. & Kapoor [2] \\
\hline & $\begin{array}{c}\text { R. solani, Pythium debaryanum, Sclerotinia minor, } F \\
\text { oxysporium. }\end{array}$ & Chet [55] Venkatasubbaiah [56] \\
\hline & $\begin{array}{l}\text { F. oxysporium, R. solani, Sclerotium rolfsii. Rhizoctonia } \\
\text { solani. }\end{array}$ & Singh \& Dwivedi [47] \\
\hline & Sclerotium rolfsii. & $\begin{array}{c}\text { Clavet [38] } \\
\text { Dhedi [48] } \\
\text { Datnoff [57] } \\
\text { Madne [50] } \\
\text { Karampour \& Okhowat [30] } \\
\text { Siddiqui \& Mahmood [58] }\end{array}$ \\
\hline & Fusarium oxysporium. & \\
\hline & Fusarium udum. & Bourbos [59] \\
\hline & Fo.f.sp.radicis. & Larkin \& Fravel [60] \\
\hline & Fusarium wilt of tomato. & Hazarika [61] \\
\hline & Pythium aphanidermatum. & Prasad \& Rangeswaran [51] \\
\hline & Sclerotium rolfsii. & Haggag \& El-Gamat [3] \\
\hline
\end{tabular}




\begin{tabular}{|c|c|c|}
\hline T. harzianum + T.viride & Fusarium solani, Fo.sp.ciceri, Fo.sp.radicis, R. solani. & $\begin{array}{c}\text { Haggag \& El-Gamat [3] } \\
\text { Kumar [62] }\end{array}$ \\
\hline T. harzianum + T. viren & Rhizoctonia solani. & $\begin{array}{c}\text { Kumar [62] } \\
\text { Dubey [63] }\end{array}$ \\
\hline $\begin{array}{c}\text { T. harzianum+ T. viride + T. } \\
\text { veren }\end{array}$ & Rhizoctonia bataticola. & $\begin{array}{c}\text { Dubey [63] } \\
\text { Shoresh [64] }\end{array}$ \\
\hline T. asperellum & Pseudomonas syringae. & \\
\hline T. parceanamosum & Data not available & \\
\hline
\end{tabular}

Table 1: Efficacy of Trichoderma species against Soil borne Plant Pathogenic Fungi and nematodes.

These species of Trichoderma varies not only from region to region or states to states but also from soil to soil and the substrate on which it grows $[5,7,65]$ as evident for its distribution in India (table.2) and around the globe.

\begin{tabular}{|c|c|c|}
\hline SR. No & Trichoderma species & State/Soils/substrate \\
\hline 1. & T. atroviride & Himalayan soils \\
\hline 2. & T. citrinoviride & Forest soils of Andhra Pradesh \\
\hline 3. & T. Flavofuscum & Rhizosphere of Oak trees in Uttaranchal \\
\hline 4. & T. hamatum & Soils of New Delhi, Southern India, and Tamil Nadu \\
\hline 5. & T. harzianum & Soils of Karnataka, Maharashtra \\
\hline 6. & T. Koningii & $\begin{array}{l}\text { Soils of New Delhi, Himachal Pradesh, Jammu, Punjab, Madhya Pradesh, } \\
\text { Chhattisgarh, Uttar Pradesh, Orissa, Assam, Meghalaya, }\end{array}$ \\
\hline 7. & T. longibrachiatum & Soils of Madhya Pradesh, Tamil Nadu, on sugarcane bagasse. \\
\hline 8. & T. piluliferum & Soils of New Delhi and South India \\
\hline 9. & T. polusporum & Soils of Kashmir \\
\hline 10. & T. pseudokoningii & $\begin{array}{l}\text { Soils of Punjab and Pantnagar in Uttar Pradesh, from decomposing paddy } \\
\text { in Kurukshetra in Haryana and on Cattle feed in Uttar Pradesh }\end{array}$ \\
\hline 11. & T. viride & $\begin{array}{l}\text { Soils of Tamil Nadu, Karnataka, Andhra Pradesh, Bihar, Rajasthan, } \\
\text { Maharashtra. Grassy soils of Varanasi, Rhizosphere of pigeon pea in central } \\
\text { and southern states and rhizosphere of sugarcane in Maharashtra. }\end{array}$ \\
\hline 12. & T. lignorum & Soils of West Bengal, Uttar Pradesh, Assam \\
\hline 13. & T. virens & $\begin{array}{l}\text { Soils of poultry farm in Jammu, Himachal Pradesh, coconut garden soils of } \\
\text { Kerala. }\end{array}$ \\
\hline
\end{tabular}

Table 2: Distribution of Trichoderma species in Indian soils.

Thus it is evident that different geographical region within the country is dominated by certain species of Trichoderma. One region may be dominated by one species while other region may have different species indicating the biodiversity in the species of Trichoderma across the geographical region. T. viride was most common, followed by T. koningii, T.harzianum and T. hamatum across the Indian states.

Ma [66] reported biodiversity of Trichoderma from grassland and forest ecosystem in northern China. $T$. harzianum was the dominant species with $28.2 \%$ from all isolates. The principal components analysis indicated that ecosystem was the most dominant impact factor for the species diversity of Trichoderma $s p$ with decreasing trend from the north to south of northern Xinjiang. Overall, Trichoderma spp were more frequently encountered in forest ecosystem than in grassland ecosystem.

Muniappan and Muthukumar [67] reported the influence of crop species and edaphic factor on the distribution and abundance of Trichoderma in alfisol of Sourth India where the population densities of two Trichoderma species i.e. T. 
koningii and T. viride varied significantly with crop species and their abundance. The soil pH negatively influenced relative abundance of T. koningii whereas soil $\mathrm{P}$ was positively correlated with T. viride. Further, relative abundance of T. koningii was significantly and positively correlated to relative abundance of Aspergillus fumigatus. Recently Borkar [26] reported Aspergillus niger as null hyper-parasite on Trichoderma hamatum which restrict the growth and biocontrol activity of the Trichoderma $s p$ as bio-agent. Thus besides the soil environmental and ecological factors, the presence of null hyper-parasite in the soil also affect the sustenance and biocontrol efficacy of the Trichoderma as bio-agent.

Al-Ani [68] reported that the environment conditions which affect Trichoderma growth, bioactivity and antagonism as biocontrol agent varies with the strains of Trichoderma. These major factors include temp, $\mathrm{pH}$, nutrient substrate while minor factor includes light and humidity. The temp parameter alters the Trichoderma's life phase and bioactivity. These parameters are very important in determining the efficacy of Trichoderma for use in controlling plant pathogens. Kredics [69] also reported the influence of environmental parameter on Trichoderma strains with biocontrol potentials. A series of abiotic environmental parameters including pesticides and metal ions in soil and biotic factors like presence of hyper-parasite of Trichoderma in the soil influence the biocontrol efficacy of Trichoderma. These results clearly indicate that a Trichoderma strain isolated and commercialized from a particular location may not prove effective in another geographical area having different soil ecological and environmental condition. Therefore, it seems to be important to have a geographical indication tag for the isolated and commercialized Trichoderma strain. This will clearly indicate the geographical location of its origin and its probable area of application wherein the same environment is present so that the Trichoderma strain may express to its fullest potential of biocontrol activity as every genetic system has effect of gene $\mathrm{x}$ environment interaction to express its activities $[70,71]$. Due to this fact only certain crop varieties and cultivars have geographical indication tag $[72,73]$ where these express better for their yield or other beneficial characteristics.

Different species of Trichoderma are commercialized as biocontrol product. These may be used as a single species in biocontrol formulation or more than one species may be used in the formulation. Generally, four commercialized formulation of a single species and four commercialized formulations of more than one species are available in the market around the world (Table 3).

\begin{tabular}{|c|c|c|}
\hline SR. No & Trichoderma species used in Bio-agent product & Country of Registration \\
\hline 1. & T. asperellum & Japan, Brazil, Kenya \\
\hline 2. & T. harzianum & $\begin{array}{c}\text { Colombia, Australia, New Zealand, South Africa, Kenya, } \\
\text { Zambia, Morocco, Tunisia, India, Brazil, Czech Republic, } \\
\text { Ecuador, Panama, Peru, Chile, EU }\end{array}$ \\
\hline 3. & T. koningii, T. harzianum (2) & Germany, Kenya \\
\hline 4. & T. koningii, T. harzianum, T. viride (3) & Colombia \\
\hline 5. & T. harzianum, T.viren (2)T. harzianum, T.viren, & Chile \\
\hline 6. & T.parceanamosum (3) & USA \\
\hline 7. & T.viren & EU, India \\
\hline 8. & T. viride & Ukraine \\
\hline 9. & T. viride, T.lignorum (2) & USA, China, South Africa, Honduras, Columbia, Australia \\
\hline
\end{tabular}

Table 3: Trichoderma spp based products registered in different countries.

Source: Sajjad Hyder [9]

The market of the Trichoderma as biocontrol agent varies around the world. Woo [74] reported the largest distribution of Trichoderma bio-products in Asia, succeeded by Europe, South-Central America and North America. They further reported that the majority of the labels indicated fungicidal properties, but only $38 \%$ of the marketed merchandise are registered. Ten Trichoderma species are specifically indicated but many labels indicate a generic Trichoderma $s p$ or spp mixed with list of ingredients. The $62 \%$ un-registered products in the market (Table 4) where the genesis of the product is doubtful, makes the biocontrol technology more ambiquitous. Further where the label is not available on the Trichoderma product, render them worthless in its application as biocontrol agent (Figure 1). 


\section{Journal of Ecology and Natural Resources}

\begin{tabular}{|c|c|c|c|c|}
\hline Region & Countries & $\begin{array}{c}\text { Commercial } \\
\text { product }\end{array}$ & $\begin{array}{c}\text { Registered } \\
\text { product }\end{array}$ & $\begin{array}{c}\% \text { Unregistered } \\
\text { product }\end{array}$ \\
\hline Africa & $\begin{array}{c}\text { South Africa, Kenya, Zambia, } \\
\text { Morocco, Tunisia }\end{array}$ & 9 & 9 & 0.0 \\
\hline Asia & $\begin{array}{c}\text { China, India, Indonesia, Japan, Korea, } \\
\text { Russia, Vietnam, Philippines }\end{array}$ & 100 & 8 & 92.0 \\
\hline Europe & $\begin{array}{c}\text { BE, CZ, DK, EE, ES, FI, FR, HU, IE, IT, } \\
\text { NL, SE, SI, UK, Moldavia, Ukraine, } \\
\text { Israel }\end{array}$ & 57 & 21 & 63.15 \\
\hline North America & USA, Canada & 29 & 19 & 34.48 \\
\hline Pacific & Australia, New Zealand & 22 & 10 & 54.54 \\
\hline South Central America & $\begin{array}{c}\text { Argentina, Bolivia, Brazil, Chile, } \\
\text { Colombia, Costa Rica, Cuba, Ecuador, } \\
\text { Honduras, Mexico, Panama, Peru, } \\
\text { Uruguay, Venezuela }\end{array}$ & 40 & 22 & 45.0 \\
\hline Multiple region & Ca. 17 & 16 & 15 & 6.25 \\
\hline Total & & $273 \%$ & 10438 & \\
\hline
\end{tabular}

Table 4: Distribution of Trichoderma spp based bio-product available in worldwide market. Source: Sajjad Hyder [9].
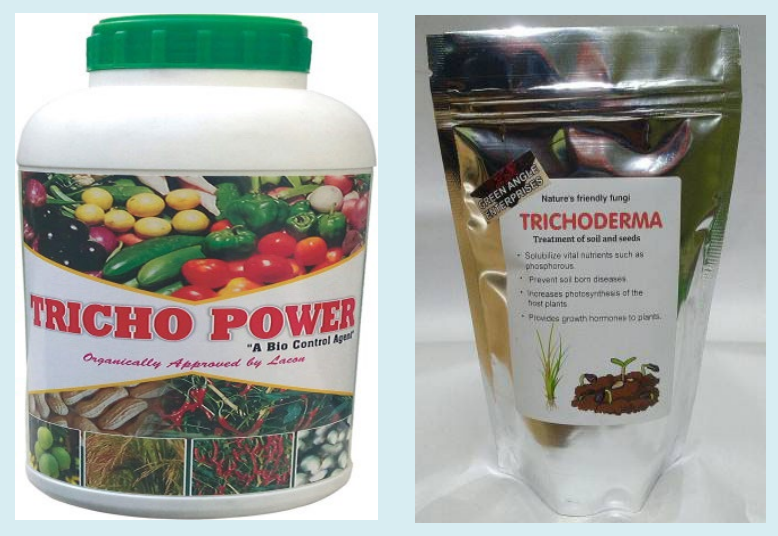

Figure 1: A marketed product of Trichoderma where the name of species and label is not mentioned. Source: Commercial market and in public domain on internet for sale promo.

Sometimes the label mentioned on the product may not hold good if the formulated strain is used in different geographical areas for its biocontrol activity. This may be due to the environmental factors as well as the different strain of the pathogen available in the region for which it was not tested. For example, though the Trichoderma harzianum species is reported to be effective biocontrol agent against Sclerotium rolfsii pathogen by Venkatasubbaiah [56], Singh and Drivedi [47], and Prasad and Rangeswaran [51] whereas the Trichoderma viride species is reported to be effective against the same pathogen $S$. rolfsii by Singh and Drivedi [47], Prasad and Rangeswaran [51], and Kappor [2], in our experimentation both these species having geographical tag of our region failed to colonies the S.rolfsii pathogen and was ineffective as biocontrol agent for $S$. rolfsii indicating the importance of the geographical tag for the trichoderma formulation. In our experiment the Trichoderm hamatum species was found to be effective biocontrol agent against the $S$. rolfsii pathogen (Table 5) rather than T.harzianum or T.viride. 


\begin{tabular}{|c|c|c|}
\hline SR. No. & Intercacting microbes & Interaction Results \\
\hline 1. & S. rolfsii + T. hamatum & $\begin{array}{l}\text { T. hamatum controlled } S \text {. rolfsii effectively. It could not allow S.rolfsii } \\
\text { to grow and the whole space was covered with Thamatum }\end{array}$ \\
\hline 2. & S. rolfsii + T. longiferum & $\begin{array}{l}\text { T.longiferum not effective in control of S.rolfsii. S.rolfsii grew in the } \\
\text { available space }\end{array}$ \\
\hline 3. & S. rolfsii + T. viride & $\begin{array}{l}\text { T. viride not effectivre in control of S.rolfsii. S.rolfsii grew in available } \\
\text { space }\end{array}$ \\
\hline 4. & S. rolfsii + T. harzianum & $\begin{array}{c}\text { T. harzianum not effective incontrol of S.rolfsii. S.rolfsii grew in } \\
\text { available space }\end{array}$ \\
\hline
\end{tabular}

Table 5: Efficacy of different Trichoderma species on groundnut foot rot pathogen S. rolfsii under in vitro experimentation.

These results clearly indicate that the inscription of Trichoderma species and the geographical tag of the biocontrol agent on the commercial formulation product is necessary to achieving the better results in the biocontrol technology [75].

\section{Conclusion}

The biocontrol agent Trichoderma has not yet achieved its impact in the agricultural production system in the biological management of plant diseases as compared to commercial synthetic fungicides. The available literature indicated that several environmental factors, soil ecology and geographical location specificity plays an important role in the efficacy of Trichoderma as biocontrol agent in the control of soil borne plant pathogens. Nevertheless, commercial formulation product of different Trichoderma species or combination of species are available as biocontrol agent for control of plant pathogens around the world and many of these products are unregistered doubting their worthiness in the biocontrol of plant pathogens. Though different Trichoderma species are registered for their bio-formulation products in different countries, seldomly the name of a species of Trichoderma and its geographical indication tag are mentioned on the commercial formulation packets. The Trichoderma species in the commercial formulation may be geographical specific for their biocontrol efficacy against a particular race or strain of the targeted pathogen. Therefore, it seems to be important to specify the species of Trichoderma and its geographical indicator tag on packet of commercial formulation product and the recommended geographical region for its biocontrol efficacy so as to derive the maximum advantage of the biocontrol product.

\section{References}

1. Sesan T (1986) Fungi to practical importance in the biological control of fungus diseases of crop plants. Industrial de cereceturi pentou projectic Plantelar, pp: 66.
2. Kapoor AS (2008) Biocontrol potential of Trichoderma spp against important soil borne diseases of vegetable crop. Indian Phytopath 61(4): 492-498.

3. Haggag KHE, El Gamat NG (2012) In vitro study on Fusarium solani and Rhizoctonia solani isolates causing the damping off and root rot diseases in tomatoes. Nature and Science 10(11): 16-25.

4. Sokhandani Z, Reza MM, Basirnia T (2016) Optimum concentration of Trichoderma longibrachiatum and cadusafos for controlling Meloidogyne javanica plants on zucchini plants. Journal of Nematology 48(1): 54-63.

5. Bilgrami KS, Jamaluddin, Rizvi MA (1979) Fungi of India. Part-II. Host Index Addenda. Today and Tomorrow publication, New Delhi. pp: 135-138.

6. Papavizas GC (1985) Trichoderma and Gliocladium: Biology, Ecology and potential for biocontrol. Ann Rev Phytopathol 23: 23-54.

7. Sarabhoy AK, Agarwal DK, Varshney JC (1992) Fungi of India 1977-1981. Associated publishing company, New Delhi.

8. Pandya JR, Sabalpara AN, Chawda SK (2011) Trichoderma: a particular weapon for biological control of phytopathogens. J Agri Technol 7(5): 1187-1191.

9. Hyder S, Inam-ul-Haq M, Bibi S, Malik AH, Ghuffar S, et al. (2017) Novel potential of Trichoderma spp as Biocontrol agent. Journal of Entomology and Zoology Studies 5(4): 214-222.

10. Zhang SW, Gan YT, Xu BI (2015) Biocontrol potential of a native species of Trichoderma longibrachiatum against Meloidogyne incognita. Appl Soil Ecol 94: 21-29.

11. Moutassem D, Belabid L, Bellik Y (2020) Efficiency of secondary metabolites produced by Trichoderma spp in the biological control of Fusarium wilt in chickpea. Journal of Crop Protection 9(2): 217-231. 


\section{Journal of Ecology and Natural Resources}

12. Somashekhar YM, Anilkumar TB, Siddarmaiah AL (1996) Biocontrol of Pigeonpea wilt. Mysore J Agric Sci 30(2): 163-165.

13. Garcia C, Marie Vivien D, Kushalappa CG, Chengappa PG, Nanaya KM (2012) Geographical indications and Biodiversity for geographical indication research in developing countries, The Economics of Intellectual Property, Chapter 4.

14. Joshi BK, Acharya AK, Gauchan D, Singh D, Ghimire KH, et al. (2017) Geographical indication: A tool for supporting on-farm conservation of crop landraces and for rural development. In: Joshi BK, et al. (Eds.), Conservation and utilization of agricultural plant genetic resources in Nepal. Proceeding of $2^{\text {nd }}$ National Workshop, May 22-23. P 50-62. NAGRC/FDD/DoA/MoAD. ISBN: 978-9937-02769-4.

15. Weindling R (1932) Trichoderma lignorum as a parasite of other fungi. Phytopathol 22: 837-845.

16. Kubicek CP, Harman GE (1998) Trichoderma and Gliocladium. Vol I \& II. Taylor and Francis ltd, London, U.K.

17. Mukhopadhyay AN, Mukherjee PK (1996) Fungi as fungicides. International J Trop Pl Dis 14(1): 1-17.

18. Brunner K, Zeilinger S, Ciliento R, Woo SL, Loroto $\mathrm{M}$ (2005) Improvement of the fungal Biocontrol agent Trichoderma atroviride to enhance both antagonism and induction of plant systemic disease resistance. Appl Environ Microbiol 71(7): 3959-3965.

19. Savazzini F, Longa CMO, Pertot I (2009) Impact of biocontrol agent Trichoderma atroviride SC1 on soil microbial communities of a vineyard in northern Italy. Soil Biol Biochem 41(7): 1457-1465.

20. Pertot I, Gobbin D, De Luca F, Prodorutti D (2008) Methods of assessing the incidence of Armillaria root rot across viticultural areas and the pathogen's genetic diversity and spatial-temporal pattern in northern Italy. Crop Protection 27(7): 1061-1070.

21. Li GQ, Huang HC, Acharya SN, Erickson RS (2005) Effectiveness of Coniothyrium minitans and Trichoderma atroviride in suppression of Sclerotinia blossom blight of alfalfa. Plant Pathology 54(2): 204-211.

22. Park YH, Mishra RC, Yoon S, Kim H, Park C, et al. (2019) Endophytic Trichoderma citrinoviride isolated from mountain cultivated ginseng has great potential as a biocontrol agent against ginseng pathogens. Journal of Ginseng Research 43(3): 408-420.
23. Patil A, Laddha A, Lunge A, Paikrao H, Mahure S (2012) In vitro antagonistic properties of selected Trichoderma species against tomato root rot causing Pythium species. Int J Sci Environ and Techno 1(4): 302-315.

24. Chung YR, Hoitnik HAJ (1990) Interaction between thermophilic fungi and trichoderma hamatum in suppression of Rhizoctonia damping off in a bark compost-amended container medium. Disease control and Pest Management 80(1): 73-77.

25. El Hassan SA, Gowen SR, Pembroke P (2013) Use of Trichoderma hamatum for biocontrol of lentil vascular wilt disease: efficacy, mechanisms of interaction and future prospects. J Plant Prot Res 53(1): 12-26.

26. Borkar SG (2020) Null hyper-parasitism, a threat for successful biological control management. European Journal of Environment and Earth Sciences 1(5).

27. Trutmann P, Keane P (1990) Trichoderma koningii as a biological control agent for Sclerotinia sclerotiorum in Southern Australia. Soil Biology and Biochemistry 22(1): 43-50.

28. Shaikh T, Sahera N (2013) In vitro assessment of antagonistic activity of Trichoderma viride and Trichoderma herzianum against pathogenic fungi. Indian Journal of Applied Research 3(5): 57-59.

29. Hadar Y, Harman GE, Taylor AG (1984) Evaluation of Trichoderma koninigii and Trichoderma harzianum from New York soils for biological control of seed rot caused by Pythium spp. Phytopathol 74(1): 106-110.

30. Karampour F, Okhowat M (1996) Effect of some isolates of antagonistic fungi on control of chickpea black rot caused by Fusarium solani under greenhouse condition. Iranian J Agric Sci 27(2): 37-43.

31. Zhang SW, Gan YT, Xu BI (2014) Efficacy of Trichoderma longibrachiatum in the control of Heterodera avenae. Bio Control 59(3): 319-331.

32. Chanu LB, Mohilal N, Shah MM (2015) Evaluation of the efficiency of some antagonistic trichoderma spp in the management of plant parasitic nematodes. In: Microbiology in Agriculture and Human Health. Published by InTech Janeza Trdine, Croatia.

33. Sreenivasaprasad S, Sreenivasaprasad M (1993) Efficacy of Gliocladium viren and Trichoderma longibrachiatum as biological control agents of groundnut root and stem rot diseases. International Journal of Pest Management $39(2): 167-171$.

34. Cuevas VC, Sinohin AM, Arro EA (2001) Efficacy of 
Journal of Ecology and Natural Resources

Trichoderma spp as biological control agent of Sclerotium rolfsii. Philippine Agricultural Scientist 84(1): 35-42.

35. Hajano J, Lodhi AM, Pathan MA, Khanzada MA, Shah GS (2012) In vitro evaluation of fungicides, plant extracts and biocontrol agents against rice blast pathogen Magnaporthe oryzae. Pakistan Journal of Botany 44(5): 1775-1778.

36. Cong Y, Fan H, Ma Q, LuY, Xu L, et al. (2019) Mixed culture fermentation between Rhizopus nigricans and Trichoderma pseudokoningii to control cucumber Fusarium wilt. Crop Protection 124: 1048-1057.

37. Thakur S, Harsh NSK (2014) In vitro potential of volatile metabolites of phylloplane fungi of piper longumas biocontrol agent against plant pathogen. IJSN 5(1): 3336.

38. Clavet C, Pera J, Bareu JM (1990) Interaction of Trichpoderma $s p$. with two wilt pathogenic fungi. Agriculture, Ecosystem and Environment 29(1-4): 5965.

39. Maheshwari DK (2001) Biological effect of Trichoderma virens on Macrophomina phaseolina causing charcoal rot of peanut. Indian Journal of Microbiology 41: 251-256.

40. Kumar S, Upadhyay JP, Rani A (2009) Evaluation of Trichoderma species against Fusarium udum, causing wilt of Pigeonpea. J Biol Control 23(3): 329-332.

41. Salas Marina MA, Isordia Jasso MI, Islas Osuna MA, Sanchez PD, Jimenez Bremont JF, et al. (2015) The Epl1 and Sm1 proteins from Trichoderma atroviride and Trichoderma virens differentially modulate systemic disease resistance against different life style pathogens in Solanum lycopersicum. Front Plant Sci 6: 77.

42. Kehri HK, Chandra S (1991) Antagonism of Trichoderma viride to Macrophomina phaseolina and its application in the control of dry root rot of mung. Indian Phytopath 41: 60-63.

43. Manjunatha SV, Naik MK, Khan MFR, Goswami RS (2013) Evaluation of biocontrol agents for management of dry root rot of chickpea caused by Macrophomina phaseolina. Crop Protection 45: 147-150.

44. John RP, Tyagi RD, Prevost D, Brar SK, Pouleur S, et al. (2010) Mycoparasitic Trichoderma viride as a biocontrol agent against Fusarium oxysporum f.sp.adzuki and Pythium arrhenomanes and as a growth promoter of soybean. Crop Protection 29(12): 1452- 1459.

45. Morshed MS (1985) In vitro antagonism of different species of Trichoderma on some seed borne fungi of bean. Bangladesh J Bot 14(2): 119-126.

46. Osman AR, Fahim MM, Saheb AF, Abdul Kedar MM (1986) Biological control of lupin wilt. Phytopath 18(1): 11-25.

47. Singh RK, Drivedi RS (1987) Studies on biological control of Sclerotium rolfsii causing foot rot of barley. Acta Botanica Indica 15: 125-127.

48. Dhedi BM, Gupta OM, Patel VA (1990) Antagonistic effect of micro-organism of Fusarium oxysporium f.sp.ciceri. Indian J Plant Path 26(1): 70-71.

49. Parveen S, Ghaffar A, Parveen S (1991) Effect of microbial antagonists in the control of root rot of tomato. Pakistan J Botany 23(2): 179-182.

50. Madne NP, Sawant DM, Kolse SV, Sapatnekar HG (1996) Management of seed and soil borne fusaria in gram by biocontrol agents. Natl Symp on Integrated Disease Management.

51. Prasad RD, Rangeswaran R (2001) Biological control of root rot and collar rot of chickpea caused by Sclerotium rolfsii. Annals of Plants Protection Sciences 9(12): 297303.

52. Kharakrang L, Kabitarani A, Upadhyay S, Upadhyay DN (2002) Disease control and growth promotion in tomato, potato and paddy by T. viride and T. harzianum. Indian J Plant Pathol 20(1-2): 30-33.

53. Prasad RD, Rangeswaran R, Hegde SV, Anuroop CP (2002) Effect of soil and seed application of Trichoderma harzianum on pigeon pea wilt caused by Fusarium udum under field condition. Crop Protection 21(4): 293-297.

54. Sharma RL, Singh BP, Thakur MP, Trimurthy VS (2003) Antagonistic effect of Trichoderma against Fusarium oxysporium f.sp.lini causing wilt of linseed. J Mycol Pl Pathol 33(3): 411-414.

55. Chet I, Elad Y, Ketan J (1980) Trichoderma harzianum: A biocontrol agent effective against Sclerotium rolfsii, Fusarium oxysporium and Rhizoctonia solani. Phytopathology 70(2): 119-121.

56. Venkatasubhaiah P, Safeevlla M, Somshekhar RK (1984) Trichoderma harzianum as a biocontrol agent for Rhizoctonia solani, the incitant of collar rot of coffee seedlings. Proc. Indian Natn Sci Acad B 50(5): 525-529.

57. Datnoff LE, Nemec S, Pernezny K (1995) Biological control of Fusarium crown rot of tomato in Florida using Trichoderma harzianum and Glotomus intraradices. Biological Control 5(3): 427-431. 
58. Siddiqui ZA, Mahmood J (1996) Biological control of Heterodera cajani and Fusarium udum on Pigeonpea by Glomus mosseae, Trichoderma harzianum and $V$. chlymadosporium. Isreal J Plant Sci 44(1): 49-56.

59. Bourbos VA, Michalopolilos G, Albages R, Camero A (1997) Biological control against Fusarium oxysporium f.sp. lycopersici on tomato in a non-heated greenhouse. Proceeding of the meeting at TenerifeCanory Islands, 3-6 Nov. Bulletin OIUB-SROP 20: 58-62.

60. Larkin RP, Fravel DR (1998) Efficacy of various fungal and bacterial biocontrol organism for control of Fusarium wilt of tomato. Plant Dis 82(9): 1022-1028.

61. Hazarika DK, Sarmah R, Paramanick T, Hazarika K, Phookan AK (2000) Biological management of tomato damping off caused by Pythium aphanidermatum. Indian J Plant Pathol 18(1-2): 36-39.

62. Kumar S (2013) Trichoderma: A biological weapon for managing plant diseases and promoting sustainability. Int J Agrl Sci Vet Med 1(3): 106-121.

63. Dubey SC, Bhavani R, Singh BK (2009) Development of Pusa 5SD for seed dressing and Pusa Biopellet 10G for soil application formulations of Trichoderma harzianum and their evaluation for integrated management of dry root rot of mungbean. Biological Control 50(3): 231-242.

64. Shoresh M, Yedidia I, Chet I (2005) Involvement of jasmonic acid/ethylene signalling pathway in the systemic resistance induced in cucumber by Trichoderma asperellum T203. Phytopathology 95(1): 76-84.

65. Kuling C, Szakacs G, Kubicek CP (2000) Molecular identification of Trichoderma spp from Russia, Siberia and the Himalaya. Mycol Res 104(9): 1117-1125.

66. Ma J, Tsegave E, Li M, Wu B, Jiang X (2020) Biodiversity of Trichoderma from grassland and forest ecosystems in Northern Xinjiang, China. 3 Biotech 10: 362.

67. Muniappan V, Muthukumar T (2014) Influence of crop species and edaphic factor on the distribution and abundance of trichoderma in Alfisol of Southern India. Acta Botanica Croatica 73(1): 37-50.

68. Al Ani LKT (2018) Trichoderma from extreme environments: Physiology, diversity and antagonistic activity. In Eurasian Ecosystem. Ecology, Diversity and Application 389-403.

69. Kredics L, Antal Z, Manczinger L, Szekeres A, Kevei F, et al. (2003) Influence of environmental parameters on Trichoderma strains with biocontrol potential. Food Technology and Biotechnology 41: 37-42.

70. Ralston A, Shaw K (2008) Environment controls gene expression: Sex determination and the onset of genetic disorder. Nature Education 1(1): 203-204.

71. Baranov S, Vinokurov I, Fedorova L (2020) Environmental factors affecting the expression of bilateral-symmetrical traits in plants. Dimensions.

72. Das K (2009) Socio-economic implications of protecting geographical indications in India. Centre for WTO studddies, New Delhi.

73. Kundan K (2018) Geographical indications in horticulture: An Indian perspective. Journal of Intellectual Property Rights 23: 159-166.

74. Woo SL, Ruocco M, Vinale F, Nigro M, Marra R, et al. (2014) Trichoderma based products and their widespread use in agriculture. The Open Myclogy Journal 8(1): 71-126.

75. Dula B, Aponyl GI, Vajna L (1987) Biocontrol of Fusarium wilt of watermelon by means of antagonistic fungus Trichoderma spp. Nevenyvedelem 23(6): 249-251. 